\title{
Effect of sunflower oil supplementation as unsaturated fatty acid source on rumen fermentability and performance of lactating Garut ewes
}

\author{
L. Khotijah, E.I. Pandiangan, D. A. Astuti and K.G. Wiryawan \\ Faculty of Animal Science, Bogor Agricultural University, \\ Jl. Agatis, Kampus IPB Darmaga, Bogor 16680 -Indonesia \\ CorrespondingE-mail:lilis.khotijah@gmail.com
}

Received December 23, 2016; Accepted March 13, 2017

\begin{abstract}
ABSTRAK
Penelitian bertujuan mengevaluasi peningkatan level energi ransum kaya asam lemak tidak jenuh dari minyak bunga matahari terhadap konsumsi zat makanan, fermentabilitas rumen dan performa induk domba pada fase laktasi. Penelitian menggunakan 15 ekor domba induk berumur sekitar 1,5 tahun, beranak pertama yang dikandangkan secara individu bergabung dengan anak-anaknya. Rancangan percobaan yang digunakan adalah Acak Lengkap 3 perlakuan 5 ulangan. Perlakuan terdiri atas R1= ransum tanpa penambahan minyak bunga matahari, $\mathrm{R} 2=$ ransum dengan $4 \%$ minyak bunga matahari, $\mathrm{R} 3=$ ransum dengan $6 \%$ minyak bunga matahari. Peubah yang diukur yaitu konsumsi bahan kering dan zat makanan, performa induk (bobot saat lahir, bobot saat sapih, penyusutan bobot badan), VFA total dan parsial, rasio acetat propionate, produksi methana, populasi bakteri dan protozoa rumen Data dianalisis statistik dan dekriptif. Perlakuan tidak mempengaruhi konsumsi bahan kering, protein kasar, serat kasar dan mineral. Perlakuan juga tidak mempengaruhi fermentabilitas rumen dan performa induk laktasi, namun konsumsi lemak dan asam lemak tidak jenuh nyata meningkat. Perlakuan mampu menurunkan nilai penyusutan bobot badan induk. Dapat disimpulkan bahwa penambahan minyak bungan matahari sebagai sumber asam lemak tidak jenuh sampai $6 \%$ dalam ransum tidak memberikan efek negative terhadap fermentabilitas rumen, dan dapat memperbaiki kondisi tubuh induk dan mempercepat pemulihan bobot badan.

Kata-kata kunci: asam lemak tak jenuh, domba garut, fermentabilitas, pemulihan, minyak bunga matahari
\end{abstract}

\begin{abstract}
The study was aimed to evaluate the increasing levels of ration energy, with fat-rich unsaturated fatty acids from sunflower oil on the nutrient intake, rumen fermentability and performance of ewes. The experiment used fifteen ewes of 1.5 years old, primiparous, caged individually with their lambs and conducted three treatments and five replications from a completely randomized designed. Those treatments included $\mathrm{R} 1=$ ration with $0 \%$ sunflower oil addition, $\mathrm{R} 2=$ ration with $4 \%$ sunflower oil addition, $\mathrm{R} 3=$ ration with $6 \%$ sunflower oil addition. The variables consisted of dry matter intake, nutrients, ewes performances (birth weight, weaning weight, decreased of body weight), total and partial VFA, the ratio of acetate: propionate, methane production, protozoa and bacterial population. Data were analyzed statistically and descriptively. The results showed that the treatments did not influence dry matter intake and nutrients,. rumen fermentability and ewes performances. Although the treatments increased $(\mathrm{P}<0.01)$ fat consumption and reduced shrinkage of body weight. It can be concluded that the adding sunflower oil as the resource of unsaturated fatty acids up to $6 \%$ of the ration was not negatively
\end{abstract}


affected the fermentability of rumen, moreover can improve ewes body condition and, accelerated body weight recovery.

Keywords: garut ewes, rumen fermentability, body weight recovery, unsaturated fatty acids, sunflower oil

\section{INTRODUCTION}

Energy is the product of nutrients metabolisms which is highly required during lactation periode. Lack or imbalance of energy during that periode may reduce production and stimulate metabolic disorders that can affect the growth of sheep offspring. During lactation, the nutrient requirement is two to three times higher than that for maintenance because the nutrients are used for body maintenance, milk synthesis, and tissue recovery that may injure during partus. NRC (2007) showed that nutrients requirement of ewes was maximum in the first month of lactation. High energy requirement of ewes postpartus should be supplied with high density energy and good quality ration. The supplementation of oil can be used as source of energy to fulfill the requirement. Fat can be more added into the lactating ruminants ration for supplying high energy along the early lactation critical period and to improve content of milk fat as well as change profile of fatty acids (Palmquist and Jenkins, 1980). Mansoori et al. (2011) reported that the use of sunflower oil at low level affected fatty acids quality and nutrients composition of milk on early lactating dairy cattle. Khotijah et al. (2015) stated that suplementation sunflower oil up to $6 \%$ improved peformance reproduction of Garut ewes.

Healthy ewes with good production and quality of milk will affect the ewes productivity and their offspring. The addition of fat into the ration increases the long chain fatty acids of milk content and directly provides fatty acids for synthesis of milk fat (Dobarganes et al., 2004; Casals et al. 2006). Around $50 \%$ of fatty acids of milk are synthesized in the acetate mammary gland contributes up to $40 \%, \beta$-hydroxybutirate $10 \%$ and the rest $(50 \%)$ from triglycerides and LDL (Low Density Lipoprotein) of blood plasma (Kaufmann and Hagemeister 1987). Triglycerides can be provided from fatty acids deposited in the cell membrane and will be re-synthesized to produce other long chain fatty acids and distributed to milk as component of milk fat.

The inclusion of oil containing long chain fatty acids such as sunflower oil is one strategy to fulfill the energy requirement qualitatively and quantitatively, therefore the objective of this research was for evaluating the sunflower oil inclusion into the lactating ewes ration on consumption, rumen fermentation, and ewes performance during lactation.

\section{MATERIALS AND METHODS}

\section{Animals and Feed}

Fifteen first month lactating Garut ewes were used in this experiment. The ewes were reared with their offspring. The ewes were fed concentrate and Brachiaria humidicola with ratio of 70:30 of ration dry matter. Concentrate consisted of coconut meal, cassava waste meal, soybean meal, $\mathrm{CaCO}_{3}$, premix, and salt. The ration treatments were: $\mathrm{R} 1=$ control (ration without sunflower oil), R2= Ration containing 4\% sunflower oil, R3 = Ration containing $6 \%$ of sunflower oil. The rations were formulated isonitrogen $(\mathrm{CP}=18 \%)$ and isoenergy $(\mathrm{TDN}=65 \%$ $68 \%$ ). Nutrients composition of rations are presented in Table 1.

Parameters tested included: nutrients consumption, rumen $\mathrm{pH}$, total and partial VFA, $\mathrm{NH}_{3}$, population of rumen protozoa and bacteria, methane production, BCS, body weight shrinkage.

\section{Procedures of Research}

Performance of Ewes during Lactation. Feed consumption during lactation was calculated by subtracting feed offered with residual feed in dry matter basis. Body weight gain was measured by weighing the ewes every week until the lambs were weaned. Efficiency of feed was calculated by segregating body weight gain with feed consumption. Body weight shrinkage was calculated by substracting body weight at weaning with body weight at partus then multiply by $100 \%$. BCS was determined by pressing body fat deposit on the backbone and heap. The BCS values for sheep were 1-5 based on (Pryce et al., 2001).

Rumen Fluid Sampling. Rumen fluid was obtained from 12 ewes at the end of lactation. Rumen fluid around $100 \mathrm{~mL}$ from each ewe was 
Table 1. Ration Nutrients Compositions Containing Sunflower Oil Different Levels

\begin{tabular}{|c|c|c|c|}
\hline \multirow{2}{*}{ Nutrients } & \multicolumn{3}{|c|}{ Treatments } \\
\hline & R1 & $\mathrm{R} 2$ & R3 \\
\hline & \multicolumn{3}{|c|}{-------------------------------\%"------------------------------ } \\
\hline Dry matter & 67.14 & 67.14 & 67.26 \\
\hline Crude protein & 18.84 & 17.83 & 18.15 \\
\hline Ether extract & 2.88 & 5.47 & 5.86 \\
\hline Unsaturated fatty acids & 0.22 & 1.59 & 1.91 \\
\hline Crude fiber & 15.27 & 15.65 & 16.01 \\
\hline NFE & 56.32 & 54.37 & 53.84 \\
\hline TDN & 65.50 & 67.60 & 68.30 \\
\hline $\mathrm{Ca}$ & 0.87 & 0.94 & 0.88 \\
\hline $\mathrm{P}$ & 0.85 & 0.73 & 0.72 \\
\hline
\end{tabular}

$\mathrm{R} 1=$ ration without sunflower oil, $\mathrm{R} 2=$ ration with $4 \%$ sunflower oil, $\mathrm{R} 3=$ ration with $6 \%$ sunflower oil

collected 4 hours after feeding using stomach tube equipment with vaccum pump. The rumen fluid $\mathrm{pH}$ was measured directly, and then added with saturated $\mathrm{HgCl}_{2}$, centrifuged to separate supernatan and sediments. The supernatan was analysed for total and partial VFA using gas chromatography, and the sediments were analysed for protozoal population based on the method of Ogimoto and Imai (1981).

\section{Data Analysis}

Completely randomized design was applied which rations containing different sunflower oil level was used as treatments. Data of consumption, body weight gain, rumen fermentability, and milk quality were analysed statistically with variance analysis and was continued to Test of Duncan Multiple Range (Steel and Torrie, 1980). Body Condition Score (BCS) was analysed descriptively.

\section{RESULTS AND DISCUSSION}

\section{Nutrients Consumption of Lactating Ewes}

Nutrients consumption of ewes fed rations containing different level of sunflower oil are presented in Table 2. The addition of sunflower oil containing unsaturated fatty acids did not affect consumption of dry matter, crude protein, crude fiber, NFE, $\mathrm{Ca}$ and $\mathrm{P}$, but significantly increased consumption of fat, unsaturated fatty acids, and the ratio of $\mathrm{Ca}: \mathrm{P}(\mathrm{P}<0.01)$. This indicated the sunflower oil ratio addition did not have negative impact on the ration palatability and nutrients intake. Similar result is reported by Pulina et al. (2006) said that the vegetable oil addition to the rations did not affect dry matter consumption. Furthermore, the use of sunflower oil and algae rich in unsaturated fatty acids do not influence dry matter consumption in ewes (Toral et al., 2010). Better consumption of R2 indicated that $4 \%$ sunflower oil addition to the concentrate could improve the ration palatability, but at higher level $(6 \%)$ it tended to reduce feed intake. Decreasing feed intake might be due to higher energy density that would restrict feed intake. High consumption of R2 will be beneficial for ewes after partus because the ewes can produce good quality of milk and prevent high body shrinkage.

Consumption of fat and unsaturated fatty acids increased $(\mathrm{P}<0.01)$ as the level of unsaturated fatty acids improved $(\mathrm{P}<0.01)$ as the level of sunflower oil in the rations increasing. The increase of fat consumption without affecting dry matter consumption is beneficial for growth and milk production, because fat in the ration is an energy source for ewes maintenance and milk production, and indirectly supply unsaturated fatty acids. One of the unsaturated fatty acids that is high in sunflower oil is linoleic acid. Linoleic acid is required to synthesize arachidonic acid and other long chain, unsaturated fatty acids with same as a precursor of prostaglandin synthesis 
Table 2. Nutrients Consumption of Lactating Ewes Fed Rations Containing Different Level of Sunflower Oil

\begin{tabular}{|c|c|c|c|}
\hline \multirow[b]{2}{*}{ Nutrients } & \multicolumn{3}{|c|}{ Rations } \\
\hline & $\mathrm{R} 1$ & $\mathrm{R} 2$ & R3 \\
\hline & &..$\left(\mathrm{g} \mathrm{h}^{-1} \mathrm{~d}^{-1}\right) \ldots \ldots \ldots \ldots$ & \\
\hline Dry matter & $929.80 \pm 199$ & $1069.50 \pm 172$ & $962.18 \pm 128$ \\
\hline Crude protein & $192.15 \pm 16.44$ & $200.85 \pm 35.48$ & $180.32 \pm 31.70$ \\
\hline Ether extract & $29.89 \pm 2.55^{\mathrm{b}}$ & $64.20 \pm 13.11^{\mathrm{a}}$ & $58.24 \pm 12.3^{\mathrm{a}}$ \\
\hline Unsaturated fatty acids & $0.07 \pm 0.01^{\mathrm{b}}$ & $1.31 \pm 0.33^{\mathrm{a}}$ & $1.47 \pm 0.36^{\mathrm{a}}$ \\
\hline Crude fiber & $146.60 \pm 14.63$ & $158.89 \pm 16.86$ & $159.30 \pm 19.19$ \\
\hline NFE & $571.22 \pm 49.09$ & $607.25 \pm 103.67$ & $534.97 \pm 89.78$ \\
\hline $\mathrm{Ca}$ & $8.82 \pm 0.76$ & $10.64 \pm 1.91$ & $8.72 \pm 1.53$ \\
\hline $\mathrm{P}$ & $8.82 \pm 0.75$ & $8.37 \pm 1.57$ & $7.18 \pm 1.36$ \\
\hline $\mathrm{Ca}: \mathrm{P}$ & $1.0 \pm 0.00^{\mathrm{c}}$ & $1.30 \pm 0.01^{\mathrm{a}}$ & $1.22 \pm 0.02^{\mathrm{b}}$ \\
\hline
\end{tabular}

Mean with different superscript indicates significantly different $(\mathrm{P}<0.05)$; $\mathrm{R} 1=$ ration without sunflower oil, $\mathrm{R} 2=$ ration with $4 \%$ sunflower oil, $\mathrm{R} 3=$ ration with $6 \%$ sunflower oil.

which has a role in curing an injured tissue after partus. In general, based on NRC (2007) the consumption of protein, fat, and crude fiber is sufficient for lactating ewes.

\section{Rumen Fermentation}

In ruminants, polyunsaturated fatty acids (PUFA) in the ration are biohydrogenized in the rumen as much as $86 \%$ for linoleic acid and $82 \%$ for linolenic acid (Jenkins dan Bridges 2007). Some vegetable oils are more resistance to biohydrogenation than others (Murphy et al., 1987). Other researchers reported that linoleic and linolenic acids were hydrogenated in the rumen as much as $70-95 \%, 85-100 \%$, in a row (Doreau and Ferlay 1994). Castro et al. (2009) reported that the inclusion of oil containing unsaturated fatty acids affected rumen function. Some indicators of rumen conditions of ewes consumed rations containing different level of sunflower oil are presented in Table 3.

The sunflower oil addition until $6 \%$ to the ration of ewes did not influence the rumen $\mathrm{pH}$, total amount of VFA, acetate, propionate, butyrate, valerate, and iso-valerate. These many output are similar as the experimental results of Jalc et al. (2007) that that use oleate, linoleate, and alfa lioleate in the ration based on lucerne and barley using Rusitec method (Hristov et al., 2005) with $5 \%$ oil into the cattle ration. Szumacher-
Strabeh et al. (2009) and Tores-Perez et al. (2011) use $5 \%$ oil in the sheep ration. According to Bhatt et al. (2011), rumen $\mathrm{pH}$ is not affected by the increasing amount $7.5 \%$ coconut oil to the the sheep ration. Cieslak et al. (2006) stated that rumen $\mathrm{pH}$ was not influenced by the improving level of vegetable oil in the rations. Rumen $\mathrm{pH}$ is still in the normal range between 5.5-7.0 (Dehority, 2004). VFA concentration ranged between 83.94 - $98.59 \mathrm{mM}$ and higher than in vitro study reported by Szumacher- Strabeh et al. (2009), that ranged between $47.5-54.07 \mathrm{mM}$ with the addition of $5 \%$ oil into the ration. Tores-Perez et al. (2011) add 1\% sunflower oil into sheep ration produce VFA around 116-174 mM. In general, the VFA concentration in this study was in the normal range for healthy rumen fermentation.

There was improving proportion of propionate, in contrast the acetate proportion is reduced. This was in line with the reduction of protozoa population. same as that stated by Onetti et al. (2001) that the fat addition into cattle ration increases the ratio of propionate to acetate and reduces protozoa population. The increase of propionate is important to supply glucose through gluconeogenesis process. The changes of acetate to propionate ratio is also possible because the increasing biohydrogenation process of rumen unsaturated fatty acids inside the rumen, so that 
Table 3. Fermentabiliy of Nutrients in the Rumen of Lactating Ewes Fed Rations Containing Different Levels of Sunflower Oil

\begin{tabular}{lrrr}
\hline \multirow{2}{*}{\multicolumn{1}{c}{ Parameter }} & \multicolumn{3}{c}{ Rations } \\
\cline { 2 - 4 } & \multicolumn{1}{c}{$\mathrm{R} 1$} & \multicolumn{1}{c}{$\mathrm{R} 2$} & \multicolumn{1}{c}{$\mathrm{R} 3$} \\
\hline $\mathrm{pH}$ & $6.01 \pm 0.47$ & $6.16 \pm 0.06$ & $5.99 \pm 0.20$ \\
Total VFA $(\mathrm{mM})$ & $83.94 \pm 30.97$ & $98.59 \pm 14.93$ & $96.33 \pm 22.76$ \\
Acetate $(\mathrm{mM})$ & $51.43 \pm 15.73$ & $53.84 \pm 13.17$ & $49.61 \pm 10.27$ \\
Propionate $(\mathrm{mM})$ & $20.30 \pm 8.87$ & $29.61 \pm 2.37$ & $30.41 \pm 8.69$ \\
Butyrate $(\mathrm{mM})$ & $8.06 \pm 4.74$ & $9.65 \pm 1.47$ & $11.58 \pm 3.91$ \\
Isobutyrate $(\mathrm{mM})$ & $0.51 \pm 0.18$ & $0.54 \pm 0.30$ & $0.46 \pm 0.18$ \\
Valerate $(\mathrm{mM})$ & $1.69 \pm 1.48$ & $3.03 \pm 0.77$ & $2.52 \pm 1.01$ \\
Isovalerate $(\mathrm{mM})$ & $1.95 \pm 1.23$ & $1.93 \pm 1.50$ & $1.75 \pm 0.52$ \\
Ammonia $(\mathrm{mM})$ & $4.45 \pm 2.76$ & $3.99 \pm 1.93$ & $2.38 \pm 1.12$ \\
Acetate:Propionate $(\mathrm{C} 2 / \mathrm{C} 3)$ & $2.71 \pm 0.63$ & $1.83 \pm 0.46$ & $1.66 \pm 0.17$ \\
Methane production ${ }^{*}(\mathrm{mM})$ & $20.79 \pm 6.30$ & $19.94 \pm 6.01$ & $18.59 \pm 3.79$ \\
Protozoa $\left(10^{4}\right.$ cell $\left.\mathrm{mL}^{-1}\right)$ & $9.87 \pm 5.02$ & $6.27 \pm 2.05$ & $6.13 \pm 1.05$ \\
Bacteria $\left(10^{9}{\left.\text { cell } \mathrm{mL}^{-1}\right)}^{5}\right.$ & $5.46 \pm 1.08$ & $6.65 \pm 2.26$ & $6.74 \pm 4.02$ \\
\hline
\end{tabular}

*) Calculated based on Moss et al. (2000). Moss et al. (2000). Methane production result= 0.45 (acetate) -0.275 (propionate) +0.40 (butyrate)

$\mathrm{R} 1=$ ration without sunflower oil, $\mathrm{R} 2=$ ration with $4 \%$ sunflower oil, $\mathrm{R} 3=$ ration with $6 \%$ sunflower oil.

hydrogen produced during fermentation can be used and consequently reduces methane production. Production of $\mathrm{NH}_{3}$, population of protozoa, and methane production tended to decline, but bacterial population tended to improve with the increasing sunflower oil level inside the rations although statistically was not different. Hristov et al. (2005) stated that the poly-usaturated fatty acids addition could reduce protozoa population and rumen VFA. Concentration of $\mathrm{NH}_{3}$ in this experiment smaller than that stated by Bhatt et al. (2011). This might be because the slow degradation of protein from coconut meal used in this experiment, so that the production of $\mathrm{NH}_{3}$ was slow. In contrast, bacterial population was high that needed $\mathrm{NH}_{3}$ for their growth, so that the concentration of $\mathrm{NH}_{3}$ was getting lower.

Protozoa population was in the normal range between $10^{4}$ cell $\mathrm{mL}^{-1}$ to $10^{6}$ cell $\mathrm{mL}^{-1}$ rumen fluid (Kamra, 2005). Bacterial population was also in the normal range between $10^{9}$ cell $\mathrm{mL}^{-1}$ to $10^{10}$ cell $\mathrm{mL}^{-1}$ rumen fluid (McDonald et al., 2002).
Normal rumen microbial population might be supported by normal rumen $\mathrm{pH}$. This condition means that the inclusion up to $6 \%$ of sunflower oil into lactating ewes does not interfere rumen microbial growth in the rumen.

\section{Performance of Ewes}

Performance of ewes such as Body Condition Score (BCS) prior to partus, weight after partus, weight at weaning, body weight shrinkage and total body weight of lambs are showed in Table 4. Ewes Body weight post partus and at at weaning was not significantly different amongst treatments. This is in line with dry matter consumption which is also not affected by sunflower addition in the rations. Ewes fed rations containing sunflower oil had body weight shrinkage 68\% (R2) and 86\% (R3) lower than ewes fed ration without sunflower oil (R1). Body weight lost indicated that feed intake or fat deposit were used for milk production, body recovery after partus, recovery of reproduction tissues after partus, and preparation for next reproduction (NRC, 1985). 
Table 4. Performance and Productivity of Ewes Fed Rations Containing Different Level Sunflower Oil

\begin{tabular}{lccc}
\hline \multicolumn{1}{c}{ Parameters } & \multicolumn{3}{c}{ Rations } \\
\cline { 2 - 4 } & \multicolumn{1}{c}{$\mathrm{R} 1$} & $\mathrm{R} 2$ & \multicolumn{1}{c}{$\mathrm{R} 3$} \\
\hline BCS pre-partum & $1.80 \pm 0.76$ & $2.30 \pm 0.58$ & $2.30 \pm 0.25$ \\
Weight pre-partum $(\mathrm{kg})$ & $33.04 \pm 2.40$ & $34.88 \pm 2.08$ & $32.27 \pm 3.38$ \\
$\quad$ Weight at weaning $(\mathrm{kg})$ & $31.46 \pm 1.62$ & $34.48 \pm 4.02$ & $31.68 \pm 3.31$ \\
$\quad$ Body weight shrinkage (\%) & 4.10 & 1.35 & 1.28 \\
$\quad$ Lamb weight gain pre-weaning $\left(\mathrm{g} \mathrm{h}^{-1} \mathrm{~d}^{-1}\right)$ & $112.75 \pm 22.97$ & $106.94 \pm 40$ & $122.95 \pm 35.71$ \\
Total lamb body weight at weaning $\left(\mathrm{kg} \mathrm{ewe}^{-1}\right)$ & $11.20 \pm 2.68$ & $13.40 \pm 5.03$ & $10.00 \pm 4.09$ \\
R1= ration without sunflower oil, R2=ration with $4 \%$ of sunflower oil, R3=ration with $6 \%$ of sunflower \\
oil
\end{tabular}

Low body weight loss in ewes fed rations containing sunflower oil indicated that sunflower oil provided energy source that can prevent the use of fat and tissue deposit in the body for milk production. Low body weight lost is expected to accelerate the ewes to re-breeding. This outcome is similar to Ghoreishi et al. (2007) who stated that the addition of of calcium soap fatty acids into the Mehraden ewes ration had positive effect on body weight lost during lactation. As endogenous precursor of arachidonic acid, linoleic acid contained in the sunflower oil can improve the arachidonic acid incorporation into endometrium cell membrane phospholipid and synthesis of PGF2 $\alpha$ (Mattos et al. 2003), which has important role in uterine involution after partus (Katri et al. 2013). Fast recovery of uterine health after partus can improve fertility in dairy cows (Cerri et al., 2009).

BCS values in the late pregnancy (before partus) were 1.80-2.3. Those values are close to standard for pregnant ewes i.e., 2.5-3.5 (AlSabbagh et al., 1995). The sunflower oil addition as resource of unsaturated fatty acids was able to improve BCS by $27.78 \%$ from control. Higher BCS values indicated that more energy was deposited by ewes, so that it could fulfill the requirement for maintenance and milk production without mobilizing body energy deposit.

In relation to body weight gain of lambs at pre-weaning, ration with sunflower oil could provide energy during lactation. Body weight gain of lambs in R1 tended to be higher but body weight loss of ewes was also higher than R2 dan R3. This might be related to mobilization of body deposit energy to support the lambs growth. Low body weight lost of ewes fed rations containiing sunflower oil means that the protein and energy provided in the ration is sufficient to support the ewes requirement for milk production (Titi and Fatafta ,2013). Growth of ewes from partus until weaning is presented in Figure 1. The growth pattern showed that ewes fed rations containing sunflower oil as source of unsaturated fatty acids tended to have more stable body weight. In the early lactation, ewes fed with control ration (R1) had sharp decrease body weight, meanwhile ewes fed with rations containing sunflower oil (R2 and R3) started to have body weight reduction three weeks after partus. This means that the sunflower oil addition into the lactating ewe rations can maintain BCS and prevent body weight shrinkage after partus. Linoleic acid could be altered to arachidonic acid that is a precursor of eicosanoid. Eicosanoid has a role in the formation of immunity system in the body (Harizi et al. 2008). In addition, prostaglandin produced from arachidonic acid play important role in uterine involution and accelerate the recovery from imflamation post partus. Linoleic and linolenic acids are very important substances for all mammals as membrane components and precursor of prostaglandin synthesis as well as synthesis of other long chain fatty acids which have main function in the membrane, so that they are important in physiological function during growth, lactation and reproduction (Mayes, 1995). Prostaglandin type 1 (PGE1) is one prostaglandin that is synthesized from Dihomo Gama Linolenic Acid (DGLA) originated from linoleic acid of sunflower oil.

Total body weight of lambs at weaning is an 


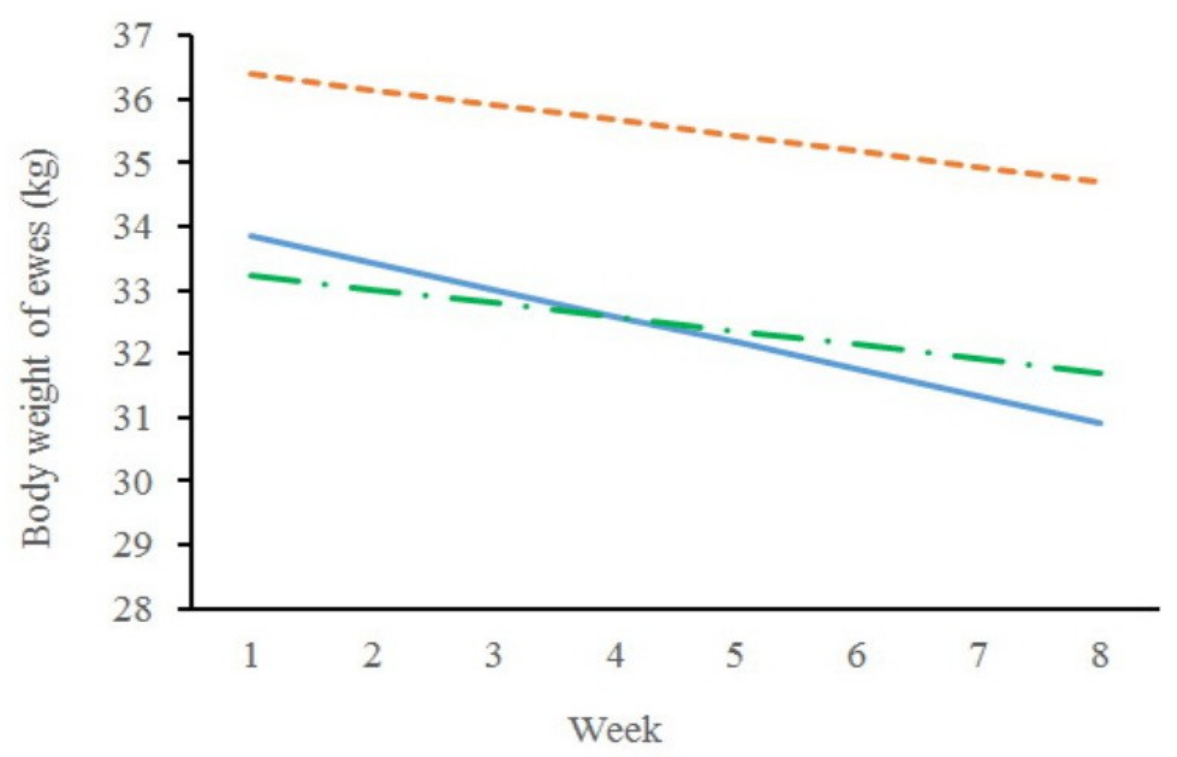

Figure 1. Growth of ewes from partus to weaning fed different rations; R1 = ration without sunflower oil ( $), \mathrm{R} 2=$ ration with $4 \%$ of sunflower oil ( --- ), R3 = ration with $6 \%$ of sunflower oil $(-\infty)$.

indicator that can describe ewes productivity (Adiati and Subandryo, 2007). Total body weight of lambs was not significantly different amongst treatments. This indicated that ewes fed rations containing sunflower oil showed improvement in productivity, because they had more twin lambs but the body weight of lambs at weaning were not different with control that had more single lamb.

\section{CONCLUSION}

The inclusion of $6 \%$ sunflower oil into the ration supported the fermentability in the rumen and showed positive response on lactating ewes productivity through improvement of body condition, and acceleration of body recovery postpartus.

\section{REFERENCES}

Adiati, U. and Subandriyo. 2007. Produktivitas ternak domba Garut pada stasiun percobaan Cilebut Bogor. Prosiding Seminar Nasional Teknologi Peternakan dan Veteriner. P436440.

Al-Sabbagh, T.A, L.V. Swanson and J.M Thomson. 1995. The effect of ewe body condition at lambing on colostral immunoglobulin $\mathrm{G}$ concentration and lamb performance. J. Anim. Sci. 73: 2860-2864.

Bhatt, R.S, N.M Soren, M.K Tripathi and S.A Karim. 2011. Effect of different levels of coconut oil supplementation on performance, digestibility, rumen fermentation, and carcass traits of Malpura lambs. Anim. Feed Sci. Technol. 164: 2937.

Casals, R., G. Caja, M.V. Pol, Such. X, E. .Albanell, A. Gargouri and J. Casellas. 2006. Response of lactating dairy ewes to various levels of dietary calcium soaps of fatty acids. Anim. Feed Sci. Tech. 131: 312-332.

Castro, T., T. Manso, V. Jimeno, M. Del Alamo and A.R. Mantecón. 2009. Effects of dietary sources of vegetable fats on performance of dairy ewes and conjugated linoleic acid (CLA) in milk. Small Rum. Res 84(1-3):47-53

Cerri, R.L.A, S.O. Juchem, R.C. Chebel, H.M Rutigliano, R.G.S. Bruno, K.N. Galvao, W.W. Thatcher and J.E.P. Santos. 2009. Effect of fat source differing in fatty acid profile on metabolic parameters, fertilization, and embryo quality in high producing dairy cows. J. Dairy Sci. 92: 
1520-1531.

Cieslak, A., R. Miltko, G. Belzecki, M. Szumacher-Strabel, A. Potkanski, E. Kwiatkowska and T. Michalowski. 2006. Effect of vegetable oils on the methane concentration and population density of the rumen ciliate Eremoplastron dilobum grown in vitro. J. Anim. Feed Sci. 15(1): 15-18.

Dehority, B.A. 2004. Rumen Microbiology. Nottingham University Press, Nottingham, United Kingdom.

Dobarganes-Garcia C., P. Hernandez, M. Cantalapiedra, G. Salas and J.M. Merino. 2004. Bypassing the rumen in dairy ewes: the reticular groove reflex vs. calcium soap of olive fatty acids. J. Dairy Sci. 88:741747.

Doreau, M. and A. Ferlay. 1994. Digestion and utilization of fatty acids by ruminants. Anim. Feed Sci. Technol. 45: 379-396.

Ghoreishi, S.M., M.J. Zamiri , E. Rowghani and H. Hejazi. 2007. Effect of calcium of fatty acids reproductive characeristics and lactation performance of fat-tailed sheep. Pakistan J. Biological Sci. 10 (14):23892395.

Harizi, H., J.B. Corcuff and N. Gualde. 2008. Arachidonic-acid-derived eicosanoid: roles biology and immunopathology. Trends Mol. Med. 14(10):461-469.

Hristov, A.N., L.R. Kennington, McGuire and C.W. Hunt. 2005. Muscles tissues of finishing cattle and nutrient digestibility, and performance and fatty acids composition of adipose and effect of diets containing linoleic acid-or oleic acid-rich oils on ruminal fermentation. J. Anim. Sci. 83:1312-1321.

Jalc, D., M. Certik, K. Kundrikova and P. Namestkova. 2007. Effect of unsaturated $\mathrm{C}_{18}$ fatty acids (oleic, linoleic, and $\alpha$ linolenic acid) on ruminal fermentation and production of fatty acids isomers in artificial rumen. Veterinarin. Medicina. 52 (3): 87-94.

Kamra, D.N. 2005. Rumen microbial ecosystem. J. Curr. Sci. 89: 124-135.

Kaufmann, W. and H. Hagemeister. 1987. Composition of Milk. In: Gravert HO (Ed) Dairy Cattle Production, Elsevier Science, New York.

Khatri, P., S.A.Tunio SA, I. Kaka, M.U. Samo, B. Bhutto and M.R. Memon. 2013. Effect of exogenous PGF2 $\alpha$ and oxytocin on postpartum anestrus and uterine involution in Kundhi buffaloes. J. Anim. Prod. Adv. 3 (4): 158-163.

Khotijah, L., K.G. Wiryawan, M.A. Setiadi and D.A. Astuti. 2015. Reproductive Performance, Cholesterol and Progesterone Status of Garut Ewes Fed Ration Containing Different Levels of Sun Flower Oil. Pakistan.J. Nutr. 14(7):388-391.

Mansoori, H., A. Aghazadeh and K.Nazeraradl. 2011. Sunflower oil seed (raw-or-heat treated) in lactating dairy cows diet:effect on milk fatty acids profile and milk production. J. Anim. Vet. Adv. 10 (4):470479.

Mattos, R., A. Guzeloglu, L. Badinga, C.R. Staples and W.W. Thatcher. 2003. Polyunsaturated fatty acids and bovine interferon modify phorbolester induced secretion of prostaglandin F2 $\alpha$ and expression of prostaglandin endoperoxide synthase- 2 and phospholipase-A2 in bovine endometrial cells. Biol. Reprod. 69:780787.

Mayes, P.A. 1995. Lipid transport and storage. In: Murray R.K., D.K. Granner, P.A. Mayes, and V.W. Rodwell (Eds). Harper Biochemistry. 24th edition. Prentice Hall International, Inc, London.

McDonald, P., R.A. Edwards, J.F.D. Greenhalgh and C.A. Morgan. 2002. Animal Nutrition. 6th Ed. Gosport (UK): Ashford Colour Press Ltd.

Murphy, M., P. Uden, D.L. Palmquist and H. Wiktorsson. 1987. Rumen and total diet digestibilities in lactating cows fed diets containing full fat rapeseed. J. Dairy Sci. 70: $1572-1582$.

NRC. 1985. Nutrient Requirement of Sheep. $6^{\text {th }}$ Revised edition. Nat. Acad.Press, Washington, D.C.

NRC. 2007. Nutrient Requirements of Small Ruminants. Nat. Acad. Press. Washington, D.C.

Ogimoto, K and S. Imai. 1981. Atlas of Rumen Microbiology. Japan Scientific Societies Press, Japan.

Onetti, S.G., R.D. Shaver., M.A. McGuire and R.R. Grummer. 2001. Effect of type and level of dietary fat on rumen fermentation and performance of dairy cows fed corn silage-based diets. J. Dairy Sci. 84: 27512759 . 
Palmquist, D.L. and T.C. Jenkins. 1980. Fat in lactation: Review. J. Dairy Sci. 63: 1-14.

Pryce, J.E., P.M. Coffey and G. Simm. 2001. The relationship between body condition score and reproductive performance. J. Dairy Sci.84:1508-1515.

Pulina, G., A. Nudda, G. Battacone and A. Cannas. 2006. Effect of nutrition on the content of fat, protein, somatic cells, aromatic compounds, and undesirable substances in sheep milk. Anim. Feed. Sci. Technol. 131: 255-261

Steel, R.G.D. and J.H. Torrie. 1980. Principles and Procedures of Statistics. McGraw-Hill Book Co. Inc. New York.

Szumacher-Strabeh, M., A. Cieslak and A. Nowakowska. 2009. Effect of oils rich linoleic acid on in vitro rumen fermentation parameters of sheep, goats, and dairy cows. J. Anim. Feed Sci. 18:440-452.
Titi, H.H. and A. Al-Fataftah. 2013. Effect of supplementation with vegetable oil on performance of lactating Awassi ewes, growth of their lambs, and on fatty acid profile of milk and blood of lambs. Archiv Tierzucht. Archives Anim. Breeding. 56:45.

Toral, P.G., G. Hervás, P. Gómez-Cortáz, P. Frutos, M. Juárez and M.A. de la Fuente. 2010. Milk fatty acid profile and dairy sheep performance in response to diet supplementation with sunflower oil plus incremental levels of marine algae. J. Dairy Sci. 93:1655-1667.

Tores-Perez A., I. Sierra, de Vega A and A.Keli. 2011. Effect of grinding size and sunflower oil addition on intake, digestibility, rumen function and microbial protein synthesis in sheep fed a total dry mixed ration. Spanish J. Agric. Res. 19(4):1186-1196. 